\title{
A QUANTITATIVE ASSESSMENT OF DIRT-GONE DYNAMICS
}

\author{
By David J. Drewry \\ (Scott Polar Research Institute, Cambridge CB2 IER, England)
}

\begin{abstract}
Quantitative investigations have been made of ice-cored dirt cones on Bersaerkerbræ in north-east Greenland. Experiments were also undertaken to evaluate field observations. Measurements included: maximum cone dimensions, sediment thickness and particle size, cone growth rates, slope angles and the temperature distribution within the debris layer and ice core. Particle size, which has not been stressed in previous studies, and related liquid consistency limits, appear as the dominant controls in cone formation, independent of debris thickness within the observed range of ro $\mathrm{mm}$ to $125 \mathrm{~mm}$. A threshold grain-size for dirt-cone inception was found, between $0.2 \mathrm{~mm}$ and $0.6 \mathrm{~mm}$. The growth of cones was usually not more than $50 \%$ of the ablation over "clean" ice. Temperature measurements within dirt cones has enabled heat-flow studies to be made, evaluating the thermal conductivity of a sediment layer and the heat transfer involved in melting the ice core. A simple model of dirt-cone dynamics is proposed, characterized by negative feedbacks and describing a steady-state system.
\end{abstract}

RÉSumÉ. Une approche quantitative de la dynamique des "cônes de poussière". Des recherches quantitatives ont été faites de cônes de poussière (dirt-cones) à noyau de glace dans le Bersaerkerbræ dans le Nord-Est du Groenland. Des expériences furent aussi entreprises avec des cônes artificiels pour contrôler les observations sur le terrain. Les mesures comprennent: les dimensions des cônes, l'épaisseur des sédiments et la taille des particules, la vitesse de croissance du cône, l'angle de la pente, la distribution des températures à l'intérieur du niveau des débris et du coeur de glace. La taille des particules et la capacité limite de rétention des liquides qui en résulte semblent être le facteur dominant qui contrôle la formation des cônes, indépendant de l'épaisseur des débris à l'intérieur de l'éventail observé, soit de 10 à $125 \mathrm{~mm}$. On a trouvé qu'il existait entre 0,2 et $0,6 \mathrm{~mm}$ une dimension-seuil des particules pour permettre la constitution des cônes. Le vitesse de croissance des cônes normalement n'était que 50\% de la taille d'ablation sur la glace "nette". Des mesures de températures à l'intérieur des cônes de poussière ont permis d'étudier les flux de chaleur, d'évaluer la conductivité thermique d'un niveau de débris et les transferts de chaleur mis en jeu dans la fusion du noyau de glace. On propose un modèle simple pour la dynamique des cônes de poussière, caractéristé par des rétroactions négatives et décrivant un système en état d'équilibre stable.

Zusammenfassung. Eine quantitative Abschätzung der Dynamik von Schuttkegeln. Quantitative Untersuchungen an Schuttkegeln mit Eiskernen wurden am Bersaerkerbræ in NO-Grönland vorgenommen. Desgleichen wurden Versuche mit künstlichen Kegeln angestellt, um die Feldbeobactungen auszuwerten. Die Messungen erfassten: Dimensionen, Sedimentmächtigkeit und Teilchengrösse, Wachstumsgeschwindigkeit des Kegels, Temperaturverteilungen innerhalb der Schuttlage und des Eiskernes sowie Böschungswinkel. Die Teilchengrösse und die damit zusammenhängenden Grenzen für den Feuchtegehalt scheinen die entscheidenden Faktoren bei der Kegelbildung zu sein, unabhängig von der Schuttdicke innerhalb des beobachteten Bereichs von Io mm bis $125 \mathrm{~mm}$. Ein Schwellwert der Korngrösse für den Schuttkegelaufbau wurde zwischen $0.2 \mathrm{~mm}$ und $0.6 \mathrm{~mm}$ gefunden. Die Wachstumsgeschwindigkeit von Kegeln war am meistens unter $50 \%$ des Ablations in reinem Eis. Temperaturmessungen in den Schuttkegeln ermöglichten Wärmeflussuntersuchungen, wobei die Wärmeleitfähigkeit einer Sedimentschicht und der Wärmetransport beim Schmelzen des Eiskernes herangezogen wurden. Ein einfaches Modell der Dynamik von Schuttkegeln wird vorgeschlagen, das durch negative Rückkopplungen und Beschreibung eines stetigen Systems charakterisiert ist.

\section{INTRODUCTION}

Dirt cones are mounds of ice- or snow-cored sediment on the surface of some glaciers. They are also known in French as "cônes graveleux des glaciers" (Agassiz, r 840); "cônes de poussières" (Bout, I956); "cônes de gravier" and "cônes couverts" (Lliboutry, I964-65, Tom. I, p. 377-78); in German as "Schmelzkegeln", "Sandkegeln" and "Termitenhügeln"; and as "debris-covered ice cones" (Sharp, I949). They range in size from a few centimetres to tens of metres in height (Fig. I). The basic mode of origin of dirt cones has been understood for many years (Spethmann and Bruckner, I908; Lewis, I940; Swithinbank, I950; Lister, I953; Wilson, I953; Streiff-Becker, 1954). Debris resting on a glacier surface protects the underlying ice, differentially, from ablation so that with the more rapid lowering of the surrounding ice surface a mound is produced (Fig. I).

Despite the common occurrence of cones, particularly on temperate glaciers, and despite the large number of published observations, few quantitative studies have been undertaken. 
The objects of this study are to present measurements taken on natural ice-cored dirt cones on the glacier Bersaerkerbræ in north-east Greenland (Fig. 2) and from experiments with artificial ice-cored cones. These quantitative observations are used in generating a working model of the thermal and mechanical processes in cone development. The effects of sediment grainsize, debris thickness, cone geometry and heat-flow characteristics in the debris layer are discussed.

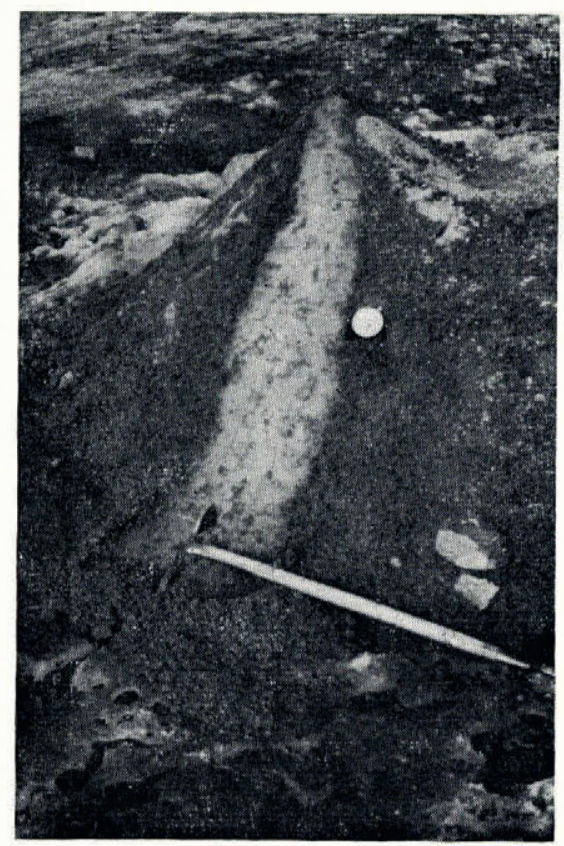

Fig. I(a). Some dirt cone on the glacier Bersaerkerbre, north-east Greenland. The ice core is shown after some of the overlying debris had been removed. Most of the coarse sand is saturated with melt water. Note the fairly uniform size of the debris.

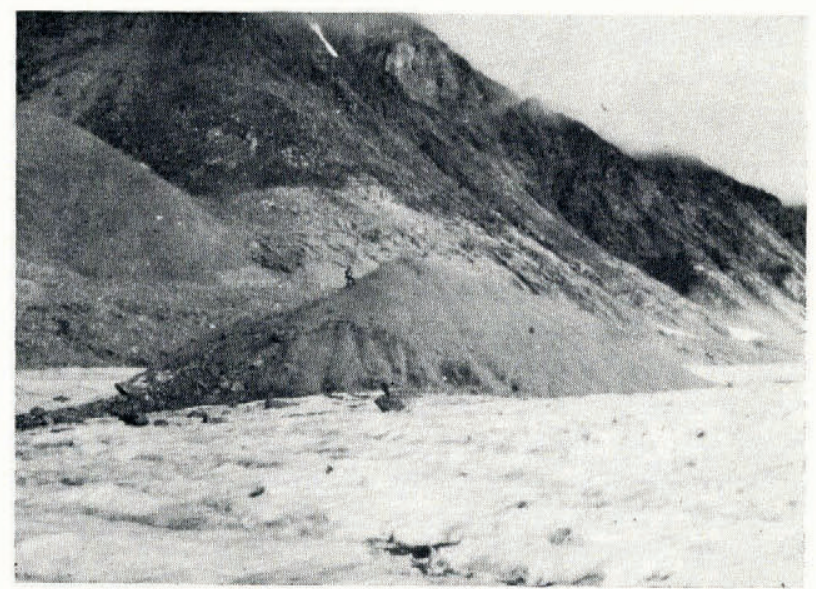

Fig." $I(b)$. Very large dirt cone on Roslin Gletscher, north-east Greenland. Figure on the cone flank gives scale. (Photograph by K. F. Miller.) 
The location of dirt cones on Bersaerkerbra is shown in Figure 2. They are concentrated in the ablation zone at the glacier margins. The debris cover of the cones is derived from a laternal moraine system: fines washed from the moraine are concentrated by surface meltstreams. Dirt cones occur in diverted, dry stream channels where there are thickenings of sediment corresponding to ancient pools and bars (Dibner and Zagorskaya, 1958). None of the cones examined appeared to originate from any other mechanism (e.g. upthrusting of debris along shear planes (Lewis, 1940) or deflation of dust and volcanic ash onto the ice surface (Krenek, I958)).

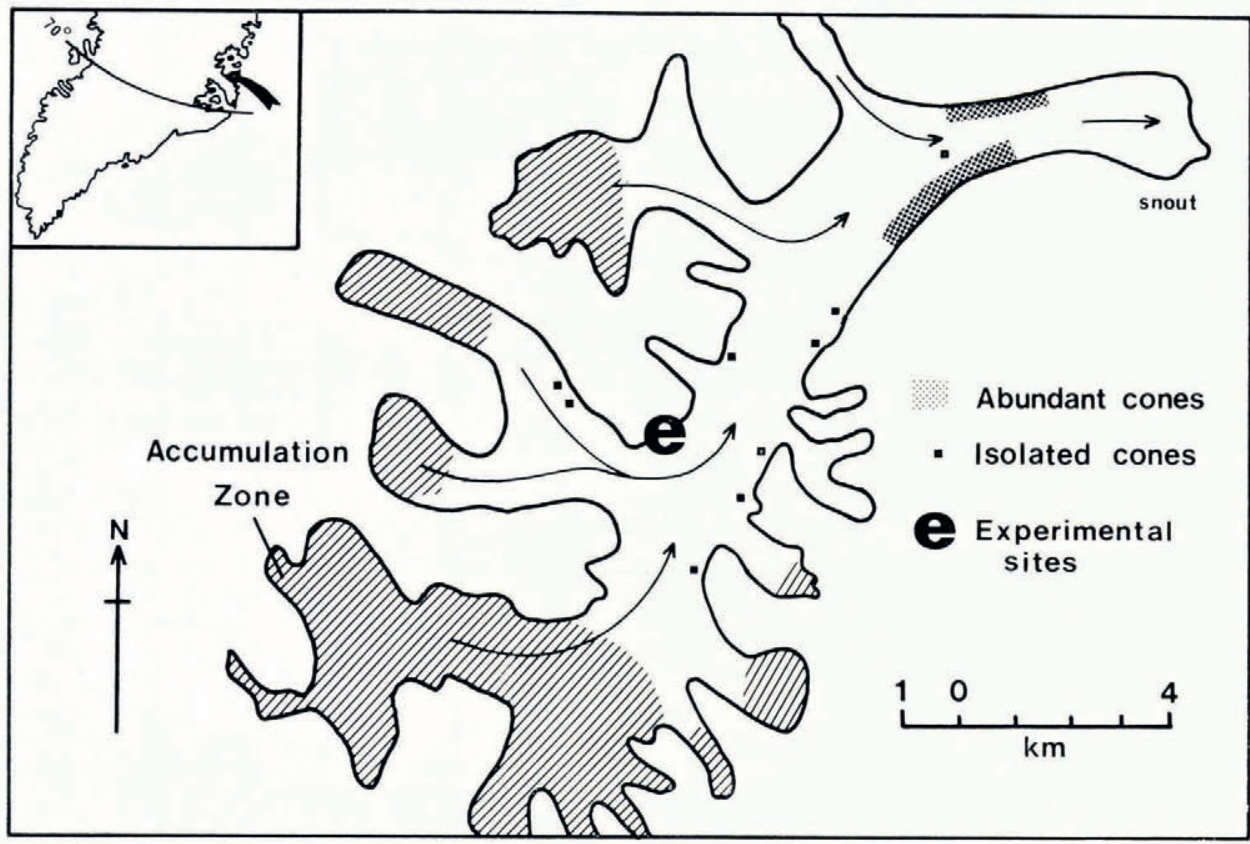

Fig. 2. Map of Bersaerkerbre, north-east Greenland showing the location of dirt cones in summer 1968.

\section{Field MeAsurements-NATURAL Dirt CONES}

Twenty cones were examined in detail. For each cone, maximum dimensions in three orthogonal directions were recorded (coordinate system shown in Figure 3). The slope of the debris was measured, by clinometer, along lines across the cone (Fig. 3). Three random lines were normally selected and between three and six angular measurements taken along each line at regularly spaced intervals up the cone slopes. The debris was subsequently scraped away and ice angles measured at locations corresponding to those at the surface (Figs. Ia, 3). The thickness of the cover, normal to the slope, was recorded at slope measurement positions. Samples were taken for particle-size analysis. The measurements for a sample of ten cones are summarized in Table I.

\section{Cone geometry}

The relationship of the maximum and minimum horizontal dimensions of the base $(x$ and $y$ dimensions) indicates that these natural cones are elliptical in plan, approximating $x=\mathrm{r} \cdot 7 y$, with elongation clearly attributed in the field to deposition in former stream channels. Average values for the ratio of the maximum to the minimum surface slopes $\tan \alpha / \tan \beta=$ 


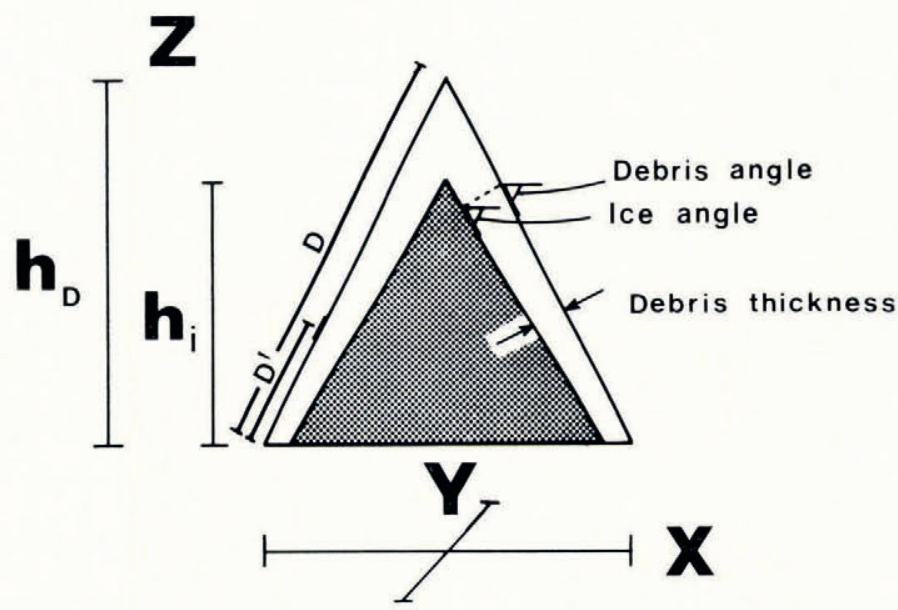

Fig. 3. Reference system for dirt-cone measurements. Height of the ice core $\left(h_{\mathrm{i}}\right)$ and debris $\left(h_{\mathrm{d}}\right)$ are measured in the $z$ direction. The maximum dimension orthogonal to $z$ determines $x$ and $y$ is the maximum measurement at right angles to $x$.

Table I. Field measurements of natural dirt cones (Bersaerkerbra, n.e. Greenland)

\begin{tabular}{|c|c|c|c|c|c|c|c|c|}
\hline \multirow{4}{*}{ Cone } & \multirow{4}{*}{$\begin{array}{c}x \\
\mathrm{~m}\end{array}$} & \multirow{4}{*}{$\begin{array}{l}y \\
\mathrm{~m}\end{array}$} & \multirow{4}{*}{$\begin{array}{l}h_{\mathrm{d}} \\
\mathrm{m}\end{array}$} & \multicolumn{3}{|c|}{ Sediment measurements } & \multicolumn{2}{|c|}{ Slope angles } \\
\hline & & & & \multicolumn{2}{|c|}{ Sediment size } & \multirow{3}{*}{$\begin{array}{c}\text { Thickness } \\
\mathrm{mm}\end{array}$} & \multirow{3}{*}{$\begin{array}{c}\theta_{\mathrm{d}} \\
\operatorname{deg}\end{array}$} & \multirow{3}{*}{$\begin{array}{c}\theta_{\mathrm{i}} \\
\text { deg }\end{array}$} \\
\hline & & & & mean & maximum & & & \\
\hline & & & & $\mathrm{mm}$ & $\mathrm{mm}$ & & & \\
\hline I & 4.93 & 2.26 & 0.84 & $0.2-2.0$ & IO & 20 & 28.4 & 30.8 \\
\hline 2 & I. 14 & $0.8 \mathrm{I}$ & 0.46 & $0.2-2.0$ & 5 & 12 & 44.1 & 32.6 \\
\hline 3 & 3.10 & 1. 83 & 0.66 & o.6-6.o & 70 & 25 & 29.7 & 32.0 \\
\hline 4 & 0.73 & 0.64 & 0.23 & $0.2-4.0$ & 50 & 20 & 33.8 & 23.1 \\
\hline 5 & 1.65 & 0.91 & 0.33 & $0.06-2.0$ & 6 & 12 & $29 \cdot 3$ & 25.8 \\
\hline 6 & 1.14 & 0.76 & 0.31 & $0.02-4.0$ & 30 & 20 & 34.2 & 31.4 \\
\hline 7 & 1.70 & 0.84 & 0.28 & $0.006-6.0$ & 50 & I 2 & 26.6 & 28.7 \\
\hline 8 & 1.32 & 0.71 & 0.42 & $0.2-6.0$ & 32 & 20 & 42.3 & 30.9 \\
\hline 9 & 1.22 & 0.66 & 0.36 & $0.06-4.0$ & 5 & 20 & 40.0 & 36.3 \\
\hline I0 & 1.09 & 0.66 & 0.45 & $0.2-6.0$ & 8 & 10 & $47 \cdot 5$ & 36.2 \\
\hline
\end{tabular}

$(2 z / y) /(2 z / x)$ approximate 0.67 . Such side-slope asymmetry is partly a function of depositional ellipticity but also due to maximum slope development occurring on those flanks receiving maximum insolation.

Slope angles were recorded on the debris cover $\left(\theta_{\mathrm{d}}\right)$ and at the ice-core/debris interface $\left(\theta_{\mathbf{i}}\right)$ and all measurements were plotted, for comparison, against their relative position, $d$, on a cone of unit size defined as

$$
d=\frac{\mathrm{IOO} D^{\prime}}{D}
$$

where $D^{\prime}$ is the height up-slope to a point of angle measurement and $D$ is the height up-slope to the crest (cone slant-length).

There appears to be a broad trend for debris angles to exceed ice angles in the central and upper parts of cones, whilst ice angles are greater in the lower part, especially the basal region (Fig. 4). Care must be taken, however, in interpreting Figure 4 and the values of $\theta_{\mathrm{d}}$ and $\theta_{\mathrm{i}}$ in Table I, since slope relationships will vary during the growth of dirt cones. In general terms, early stages of development will be characterized by $\theta_{\mathbf{d}}>\theta_{\mathbf{i}}$, later stages by $\theta_{\mathbf{d}}<\theta_{\mathrm{i}}$, see section 6 . The natural dirt cones investigated were of unknown age but were probably in the later stages of the first phase. 


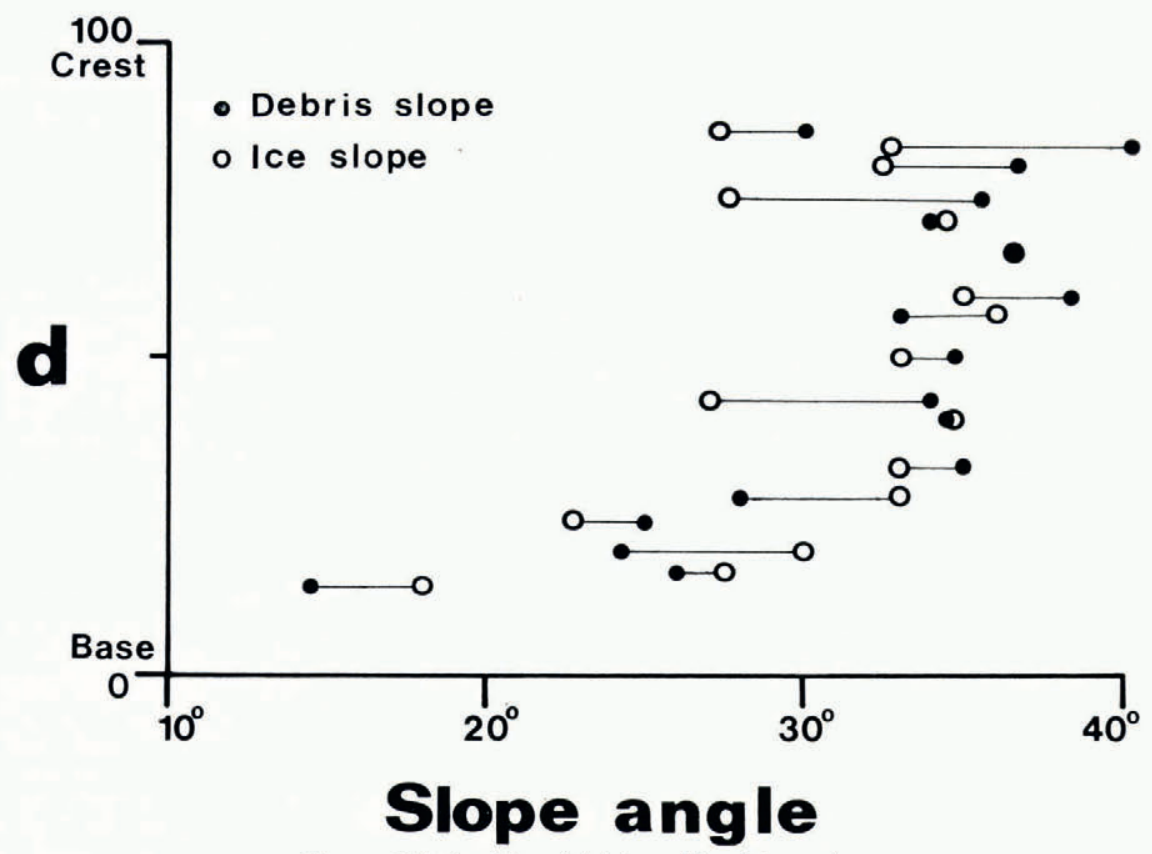

Fig. 4. Relationships of debris and ice slope angles.

Sediment characteristics

The dominant constituent of the moraine-derived sediment is a reddish-brown, ironstained quartz sand originating from the Late Precambrian quartzites which crop out along the eastern margin of the glacier (Fränkl, r953).

Debris thickness on cone flanks usually varied from $0.5 \mathrm{~mm}$ to $20 \mathrm{~mm}$, and was rarely greater than $40 \mathrm{~mm}$ (Table I). The predominant particle size in all the cones was between $0.6 \mathrm{~mm}$ and $5 \mathrm{~mm}$ (coarse sand grade). Most deposits, however, were not well sorted (Fig. 5).

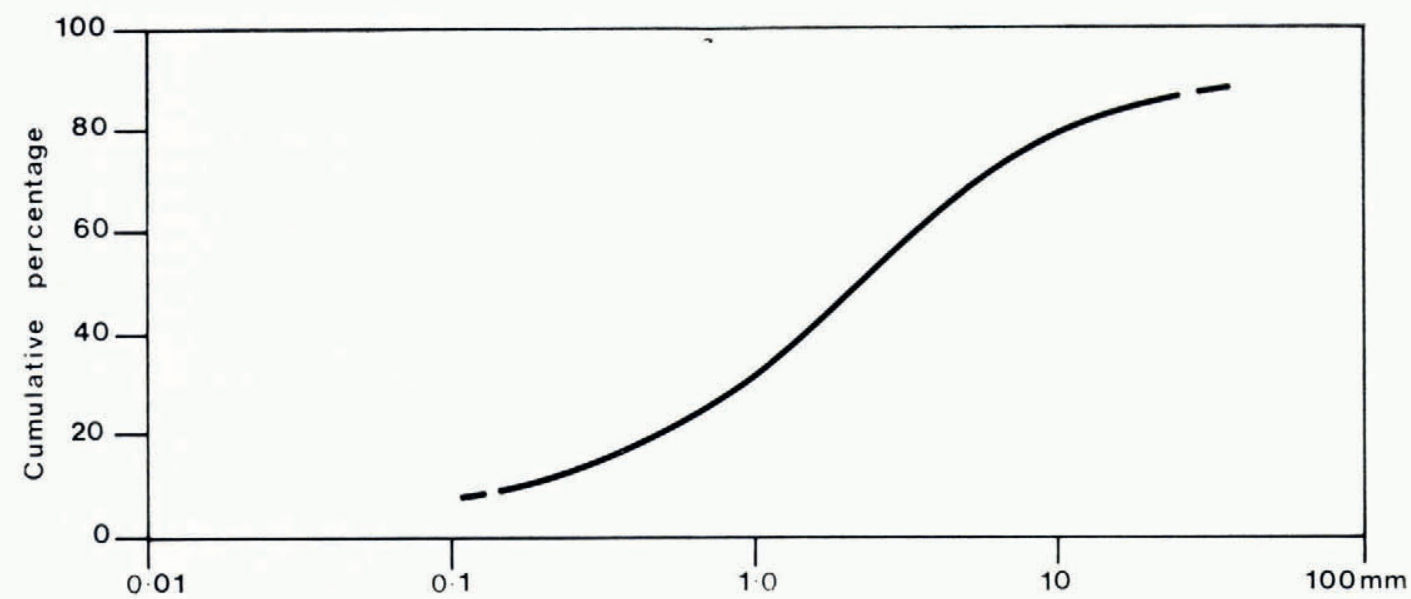

Particle size

Fig. 5. Average cumulative curve for sediment-size characteristics from a sample of ten natural dirt cones, determined by sieving through five meshes. 
The best developed cones were found in fairly well-sorted medium to coarse sand. Although finer-grained sediments were readily available at the glacier surface (e.g. silts and clays from $<0.002 \mathrm{~mm}$ to $0.06 \mathrm{~mm}$ ) no cones were developed in these materials nor in the equally abundant coarse gravels and cobbles (Io $\mathrm{mm}$ to $200 \mathrm{~mm}$ ).

\section{Experimental dirt cones}

The measurements on natural dirt cones suggested that the effect of grain size, debris thickness and plot geometry on cone growth and thermal regime should be further investigated and a series of seven experiments with artificially induced dirt cones was undertaken. Other experiments, to evaluate the effect of debris on the melting behaviour of glacier ice, snow and lake ice, have been carried out by Lister (1953), Østrem (1959, I965), Wijngaarden (I96r), Markin (in press), and Megahan and others (1970).

TABle II. EXPERIMENTAL DIRT CONES: inPUT DATA

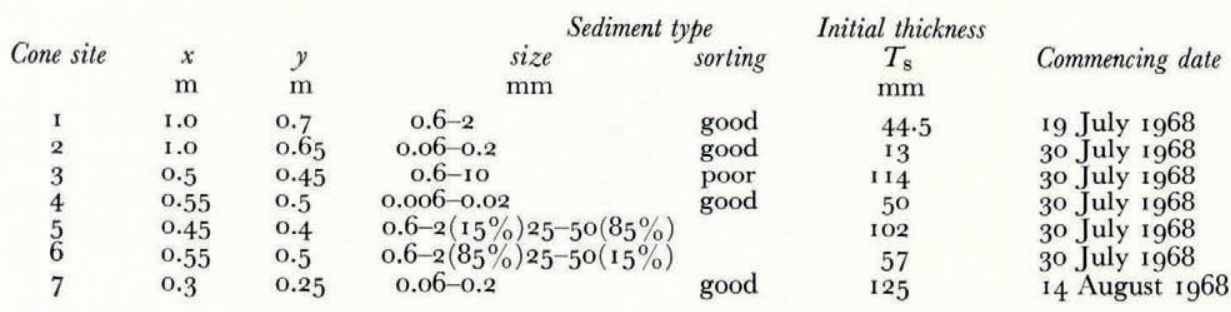

Sediment was deposited on "clean" glacier ice in three rectangular groups (approx. I.0 $\mathrm{m}$ by $0.65 \mathrm{~m}, 0.50 \mathrm{~m}$ by $0.50 \mathrm{~m}$, and $0.30 \mathrm{~m}$ by $0.25 \mathrm{~m}$ ) and in a variety of thicknesses from Io $\mathrm{mm}$ to $125 \mathrm{~mm}$ (Fig. 6). Sediment textures varied as indicated in Table II. After I4 d, sediment at some of the sites had been left upstanding relative to the ice surface. The situation at the end of the experimental period is summarized in Table III and Figure 6.

TABle III. EXPERIMENTAL DIRT CONES: OUTPUT DATA

\begin{tabular}{|c|c|c|c|c|c|c|c|c|c|c|}
\hline Cone & $\begin{array}{c}t \\
\mathrm{~h}\end{array}$ & $\begin{array}{c}x \\
\mathrm{~m}\end{array}$ & $\begin{array}{l}y \\
\mathrm{~m}\end{array}$ & $\begin{array}{l}h_{\mathrm{d}} \\
\mathrm{m}\end{array}$ & $\begin{array}{c}h_{\mathrm{d}}^{\prime} \\
\mathrm{m}\end{array}$ & $\begin{array}{l}h_{i}^{\prime} \\
\mathrm{m}\end{array}$ & $\begin{array}{c}\text { Final } \\
\text { thickness } \\
T_{\mathrm{f}} \\
\mathrm{mm}\end{array}$ & $\begin{array}{l}\text { Growth } \\
F_{\mathrm{d}}\end{array}$ & $\begin{array}{c}\text { factor } \\
\qquad F_{\mathrm{i}}\end{array}$ & $\begin{array}{l}G_{\mathrm{a}} \\
\mathrm{m}\end{array}$ \\
\hline ra & 288 & 0.84 & 0.84 & 0.217 & $0.17^{2}$ & o. 196 & 2 I & $0.35^{8}$ & 0.408 & 0.480 \\
\hline Ib & 624 & I. 15 & I. 13 & 0.355 & 0.311 & 0.339 & I6 & 0.317 & 0.346 & $0.98 \mathrm{I}$ \\
\hline 2 & 336 & 1.80 & I. 73 & & no cone & & 3 & o & o & 0.502 \\
\hline 3 & $33^{6}$ & 0.79 & 0.77 & $0.29^{2}$ & 0.1 78 & $0.27 \mathrm{I}$ & 20 & 0.355 & $0.54^{\circ}$ & 0.502 \\
\hline 4 & 336 & flowed & $6 \mathrm{~m}$ & & no cone & & 2 & o & o & 0.502 \\
\hline 5 & 336 & 0.70 & 0.62 & 0.108 & o.oo6 & 0.019 & 89 & 0.012 & $0.03^{8}$ & 0.502 \\
\hline 6 & 336 & 0.70 & 0.70 & o. 194 & o. I 37 & 0.172 & 22 & 0.273 & $0.34^{2}$ & 0.502 \\
\hline 7 & I 68 & $0.4^{I}$ & $0.3^{8}$ & & no cone & & 63 & o & o & 0.102 \\
\hline
\end{tabular}

Note: $h_{\mathrm{d}}^{\prime}=\left[h_{\mathrm{d}}-T_{\mathrm{s}}\right]$ and $h_{\mathrm{i}}^{\prime}=\left[h_{\mathrm{d}}-T_{\mathrm{f}}\right]$. These are the height increases of the debris cover and ice core respectively. $h_{\mathrm{d}}$ is the final height of the debris crest above the surrounding "clean" ice. $G_{\mathrm{a}}$ is the total ablation over "clean" ice for the period $t$.

\section{Growth rates}

A simple growth factor $F$ has been calculated to indicate the change in the mean elevation, with time, of the ice $F_{\mathrm{i}}$ and debris $F_{\mathrm{d}}$ crests with respect to ablation over a "clean" ice surface:

$$
F=h^{\prime} / G_{\mathrm{a}}
$$

where $h^{\prime}$ is the height increase of the ice or debris (see Table III) and $G_{\mathrm{a}}$ is the total ablation over "clean" ice during the period of cone growth. When $F_{\mathrm{i}}$ or $F_{\mathrm{d}}$ is equal to $\mathrm{I}$, the ice or debris growth rate is equal to the ablation rate; with $F_{\mathrm{i}}$ or $F_{\mathrm{d}}$ equal to o, there is no growth. 

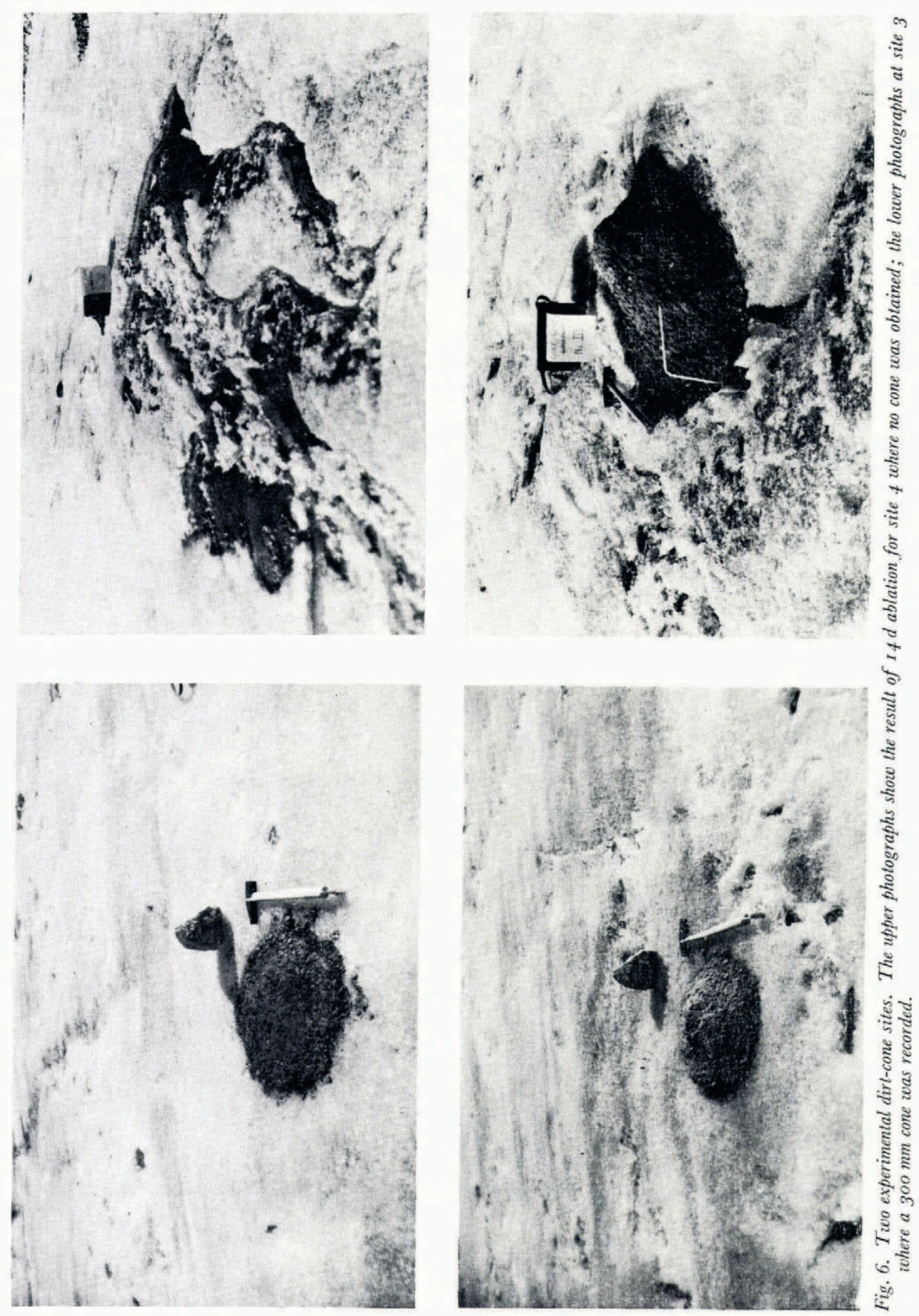
The values of $h^{\prime}, h_{\mathrm{d}}^{\prime}, G_{\mathrm{a}}, F_{\mathrm{i}}$ and $F_{\mathrm{d}}$ are given with other data in Table III. A number of significant relationships are indicated: (a) growth of experimental cones proceeds at rates of up to about $50 \%$ that of ablation over "clean" ice $(F<0.5)$; (b) cone height and basal crosssectional area are related in the same manner as for natural dirt cones (see Table I); (c) the fact that $F_{\mathrm{i}}$ is invariably greater than $F_{\mathrm{d}}$ indicates that debris thins, with time, at the crest. This progressive thinning shows in height differences in Figure 7, and is primarily a response to mass down-slope transfer, spreading sediment over an increasing cone area following continued ablation and slope change. Such a process would account for the debris and iceslope relations in Figure 4 .

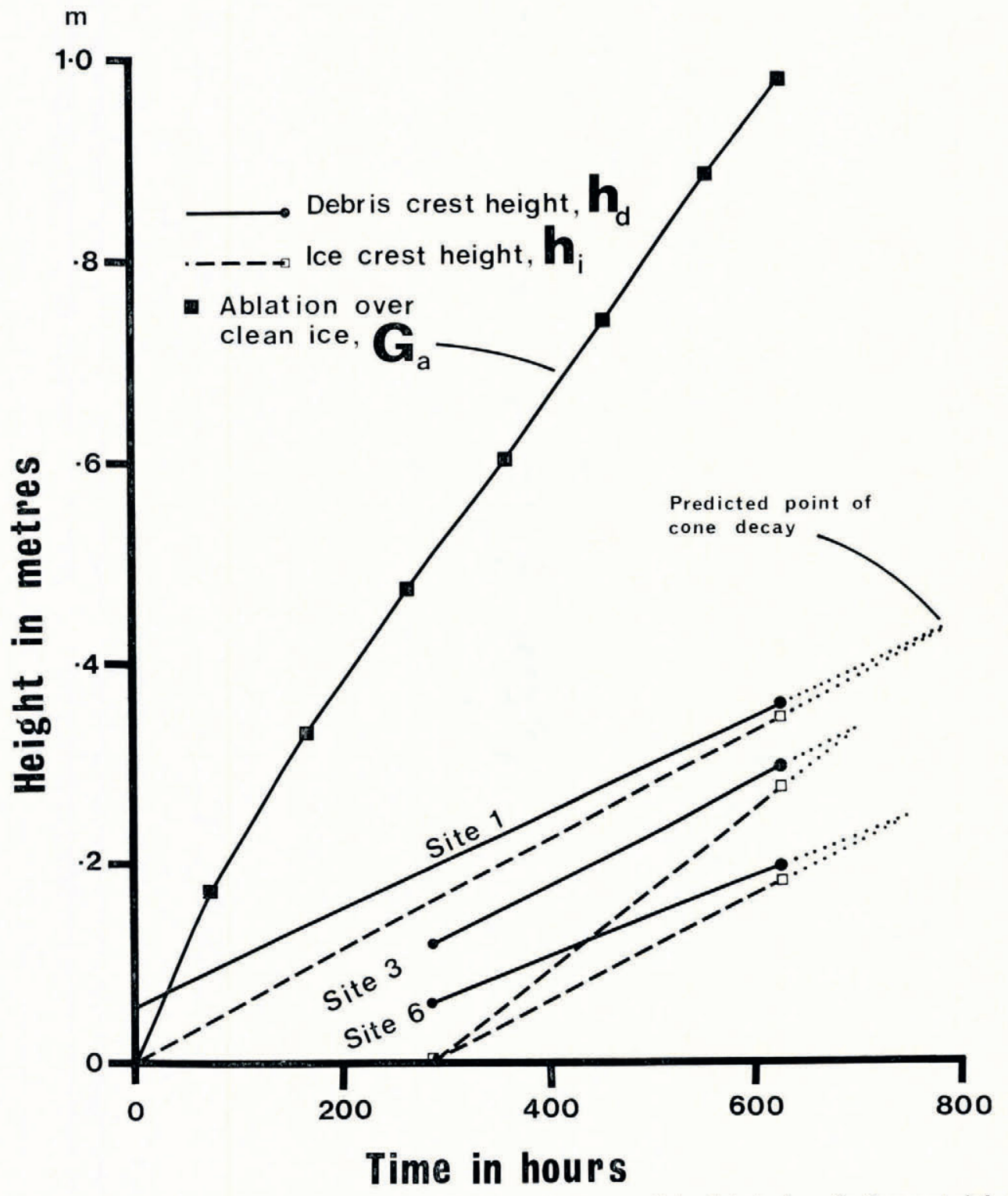

Fig. 7. Growth of debris and ice crests in experimental dirt cones. Ablation over "clean" ice is shown for the same period. The curves have been projected to their intersections, when the sediment cover should vanish from the crest. The growth rates subsequently become negative and the cone commences to be degraded. 
Particle size

Cones grew at sites I, 3, 5 and 6 where there were unimodal deposits greater than $0.6 \mathrm{~mm}$ mean grain size. Site 2, a fine, well-sorted sand, produced no cone, the sediment flowing away over the ice surface. A further experiment (site 7) confirmed that this was not a function of plot shape or thickness. The clearest case of saturated flow occurred at site 4 in a mediumgrained silt (Fig. 6). The whole sediment mass became mobilized with melt water and moved a distance of $6 \mathrm{~m}$ in $14 \mathrm{~d}$. Coarse sediments (pebbles and cobbles), in thicknesses not greater than approximately twice their mean long-axes, did not produce cones.

Figure 8 summarizes the experimental results. The mean particle size of artificial dirt cones is shown against the growth factor $F$. From these data and field observations it appears that a threshold value of sediment size can be postulated for dirt cone inception in well-sorted, unimodal deposits. According to Figure 8 this is a medium-grained sand (between $0.2 \mathrm{~mm}$ and $0.6 \mathrm{~mm}$ mean grain size) for a wide range of debris thicknesses (from io $\mathrm{mm}$ to $\mathrm{I} 25 \mathrm{~mm}$ ). Comparison with Østrem's (1965) results suggest that for greater sediment size an increasing thickness of debris will yield positive growth rates. Between the two limits shown in Figure 8 there is a gradation of cone development. The optimum grain size appears to fall in the coarse sand to fine gravel grade $(0.6 \mathrm{~mm}-5 \mathrm{~mm})$.

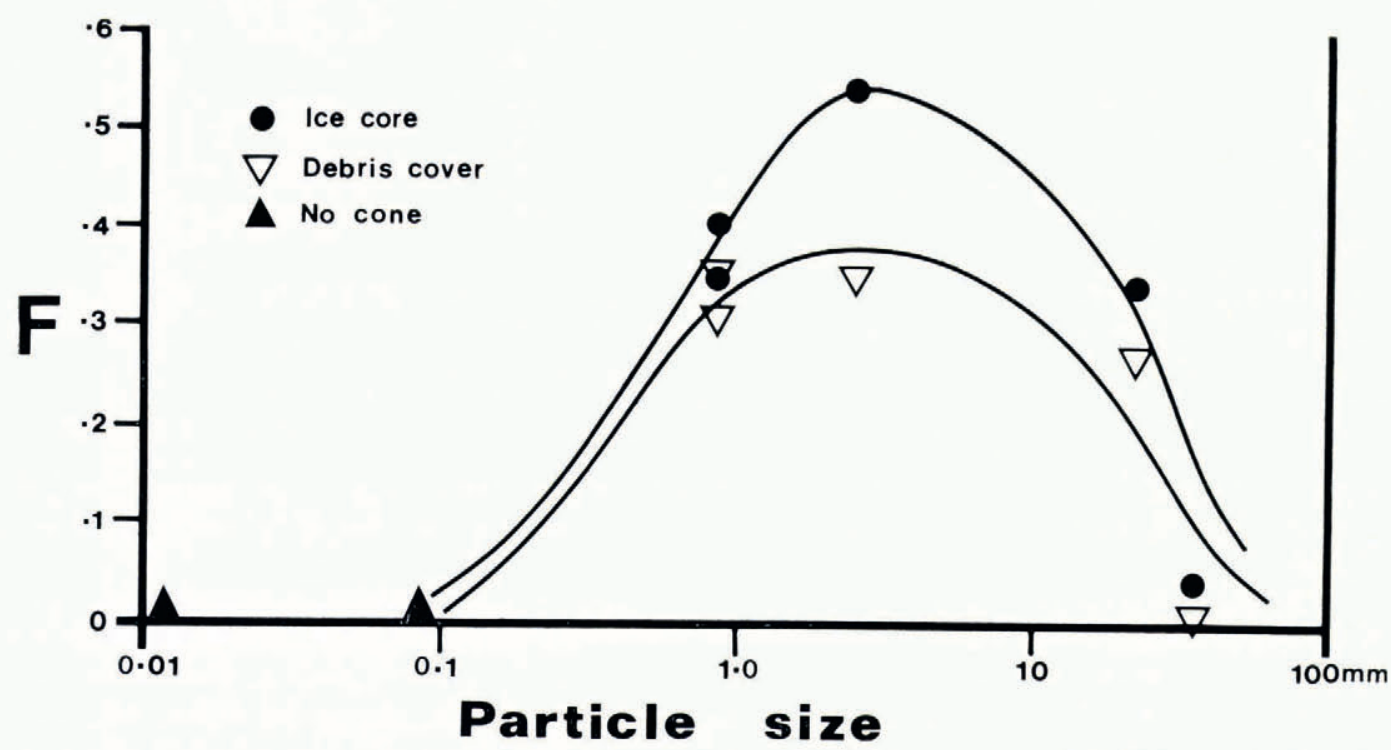

Fig. 8. Particle size of experimental dirt cones and their growth factors $F_{\mathrm{i}}$ and $F_{\mathrm{d}}$, showing a threshold for cone inception and optimum growth between $0.6 \mathrm{~mm}$ and $5 \mathrm{~mm}$.

Temperature observations

Temperatures were recorded by:

(I) A thermograph located $3 \mathrm{~m}$ from the experimental dirt-cone site.

(2) Dry bulb thermometers $300 \mathrm{~mm}$ long located: (a) In air, $30 \mathrm{~mm}$ from the debris cover and $250 \mathrm{~mm}$ above the ice surface (thermometer with a simple radiation shield); (b) $20 \mathrm{~mm}$ within a debris cover, $30 \mathrm{~mm}$ thick; (c) $30 \mathrm{~mm}$ within the dirt-cone ice core.

The maximum error in temperature measurements due to equipment sensitivity and operator variance is about $0.5 \mathrm{deg}$. Readings were taken every two hours for a $24 \mathrm{~h}$ period 
from I 2.0o h (G.M.T.) I4 August I968. Figure 9 shows the four resulting temperature curves. Although large fluctuations were recorded in both the ambient and localized air temperatures the debris cover changed by only $3.5 \mathrm{deg}$ and the ice core showed little variation from melting point.

\section{Thermal processes}

The amount of protection afforded by a sedimentary layer, and hence the growth rate of a dirt cone, depends upon the amount of heat transferred through the debris.

The total ablation over adjacent "clean" ice for the experimental period ( $26 \mathrm{~d}$ ) was $0.98 \mathrm{~m}$ ice ( $\approx 0.5 \mathrm{~m}$ water equivalent) (see Fig. 7). A mean value for the absorption of heat required to produc this amount of melt is $1.3 \times 10^{2} \mathrm{~W} \mathrm{~m} \mathrm{~m}^{-2}$. Lister (1953, 1959) reported values for summer melt over "clean" ice in Iceland which give a mean heat flux density of $3 \times \mathrm{IO}^{2} \mathrm{~W} \mathrm{~m}-2$. The rate of absorption of heat at the ice surface, beneath the debris, for experimental dirt cones can be evaluated from the melt rates as shown in Table IV.

Table IV. Calculation of heat flux to ice of Dirt cones

$\begin{array}{ccccc}\text { Site } & \begin{array}{c}\text { Duration } \\ \mathrm{h}\end{array} & \begin{array}{c}\text { Ice melt } \\ \mathrm{m}\end{array} & \begin{array}{c}\text { Water } \\ \text { equivalent } \\ \mathrm{m}\end{array} & \begin{array}{c}\text { Mean heat flow } \\ \text { through debris } \\ \mathrm{W} \mathrm{m}^{-2}\end{array} \\ \text { "clean ice" } & 624 & 0.98 & 0.90 & 130 \\ \text { I } & 624 & 0.64 & 0.57 & 85 \\ 3 & 336 & 0.23 & 0.21 & 56 \\ 5 & 336 & 0.48 & 0.44 & 18 \\ 6 & 336 & 0.32 & 0.29 & 7 \mathrm{I}\end{array}$

Using these values and the temperature gradient within the debris layer, the thermal conductivity of the material can be estinsated by:

$$
\bar{Q}=-k \frac{\overline{\partial T}}{\partial x}
$$

where $k$ is the thermal conductivity, $\bar{Q}$ the heat flow per unit area of cross-section averaged over the period, and $\partial T / \partial x$ the average thermal gradient through the debris normal to the surface.

The observed temperatures for site I (Fig. 9) are given for a distance approximately io mm from the ice-core surface. Assuming that the temperature gradient is constant throughout the debris, $\partial T / \partial x$ becomes $150 \mathrm{deg} \mathrm{m}^{-1}$. Substituting into Equation (3) with $Q=85 \mathrm{~W} \mathrm{~m}^{-2}$ we obtain $k \approx 0.56 \mathrm{~W} \mathrm{~m}^{-1} \mathrm{deg}^{-1}$. The value of $K$ can be compared with published estimates of thermal conductivities for unconsolidated, dry, sandy accumulations at $0^{\circ} \mathrm{C}$ given in Table V.

The debris layer of a dirt cone is usually charged with melt water which may have a significant effect on thermal behaviour if the conductivity of the solid is very different from that of water (Carslaw and Jaeger, 1959). The thermal conductivity of pure water is $0.5^{6}$ $\mathrm{W} \mathrm{m} \mathrm{m}^{-1} \mathrm{deg}^{-1}$, closely similar to the conductivity for the debris/water mixture. Hence, in this rather special case, water has little effect on the sediment conductivity except to make it appear less porous.

\section{Thermal regime}

Figure io has been constructed to indicate the temperature distribution in a debris layer, following a sudden change in surface temperature. Although the temperature at the surface may pass below $0^{\circ} \mathrm{C}$, melting can still take place at the debris/ice interface because of the 
time lag required for a cold wave to pass through the debris (Fig. Io). Once the cold wave has passed through the layer, all melting will cease. The time lag $(\Delta \tau)$ between a cyclic change (e.g. daily) in surface temperature (following a sine function) and that at depth within the sediment is given (after Jakob and Hawkins, I942) by:

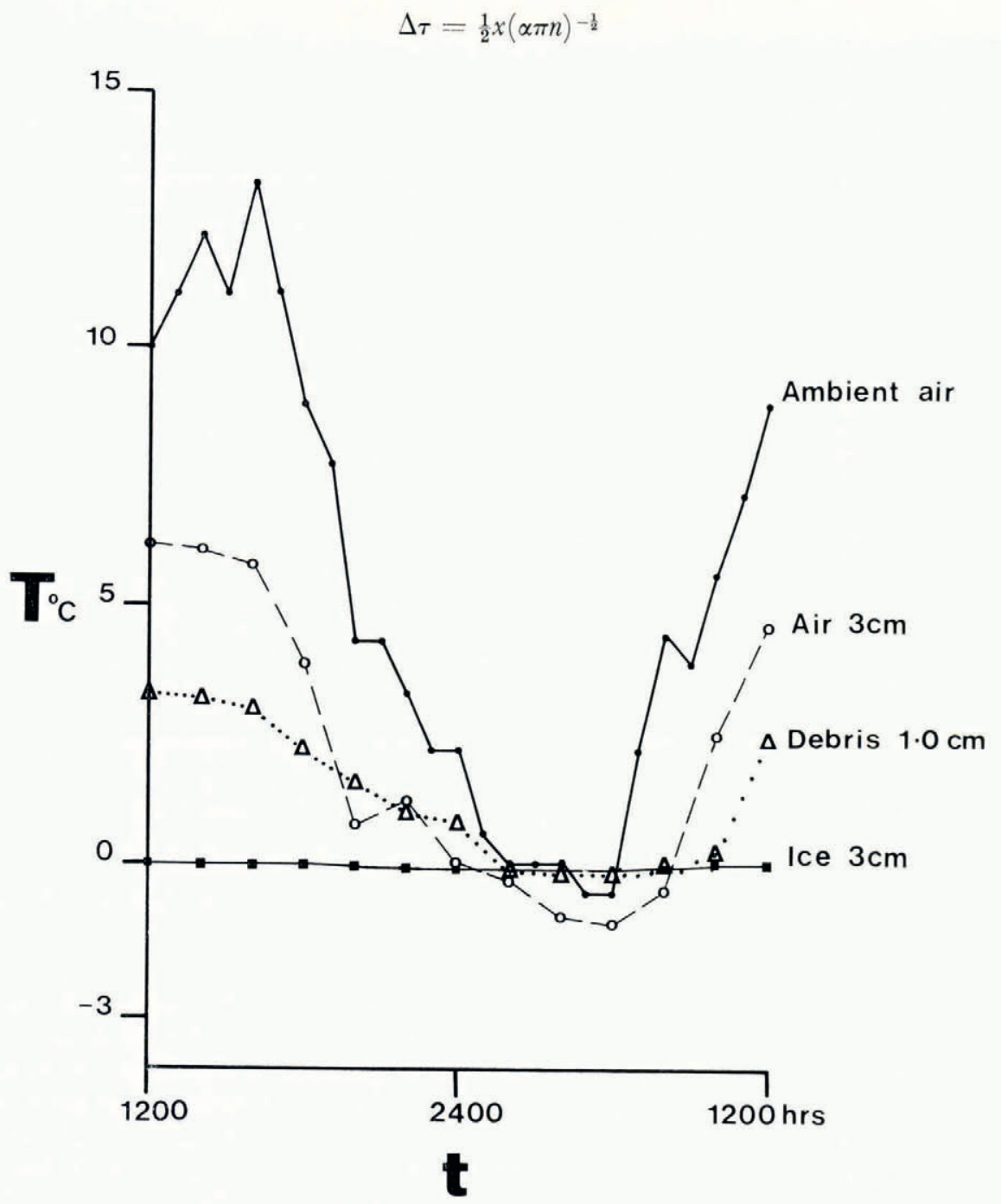

Fig. 9. Temperature curves at site I for ambient air temperature, air temperature $30 \mathrm{~mm}$ from the dirt-cone surface, Io $\mathrm{mm}$ from the debris/ice interface and $30 \mathrm{~mm}$ within the ice core. Period $24 \mathrm{~h}, \mathrm{I}_{4}{ }^{-15}$ August 1968.

TABle V. Thermal Conductivities of UnConsolidated Particles

Material

Silica (fused quartz glass)

Hudson River sand

Quartz sand (I)

Quartz sand (2)

Dirt-cone debris 
where $x$ is the distance from the debris surface, $\alpha$ the thermal diffusivity $=k / c \rho_{s}$ where $c$ is the specific heat capacity and $\rho_{\mathrm{s}}$ the density of debris, and $n$ is the number of cycles per unit time. For values of $\alpha=3 \times \mathrm{IO}^{-7} \mathrm{~m}^{2} \mathrm{~s}^{-1}$ (based on $k=0.56 \mathrm{~W} \mathrm{~m}^{-1} \mathrm{deg}^{-1}$ ) and $n=$ I. $157 \times 10^{-5} \mathrm{~Hz}, x=0.03 \mathrm{~m}$ corresponds to $\Delta \tau=\mathrm{I} .2 \mathrm{~h}$, and $x=0.02 \mathrm{~m}$ to $\Delta t=0.9 \mathrm{~h}$.

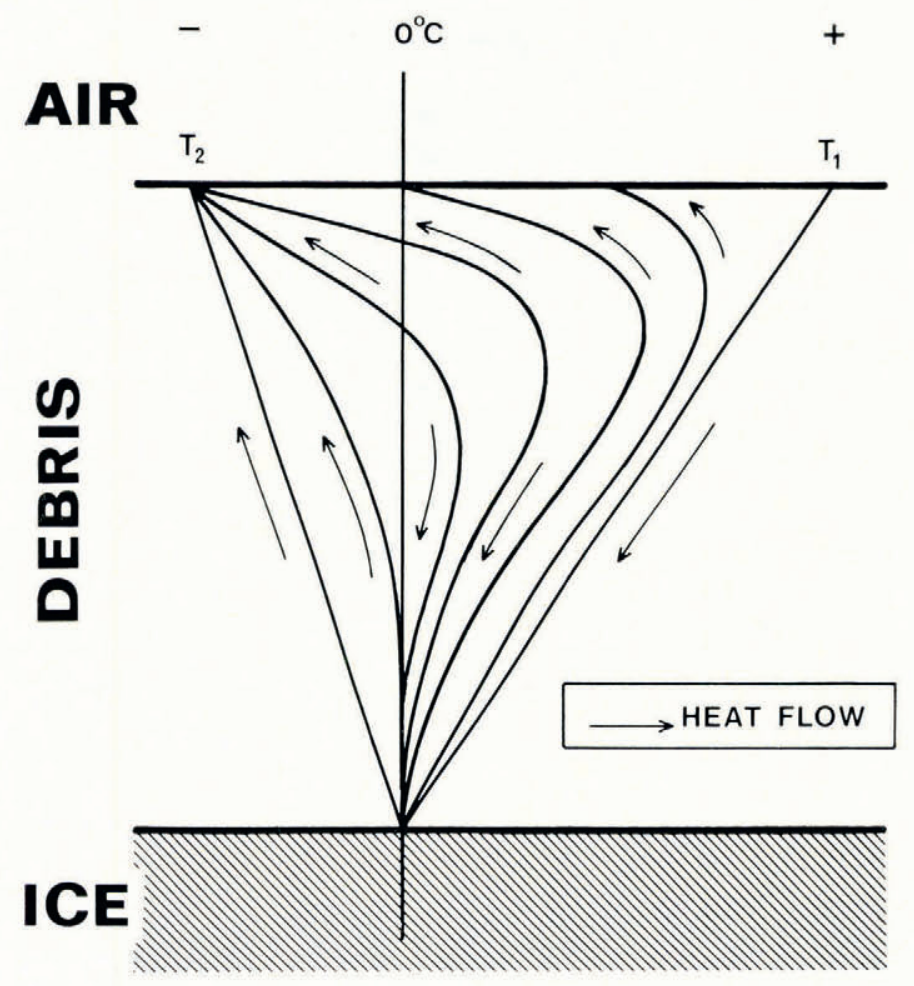

Fig. 1o. Idealized heat flow curves in a debris layer of a dirt cone following a sudden change of temperature at the surface of the debris through $o^{\circ} \mathrm{C}$, from $T_{1}$ to $T_{2}$.

Such time-lag values provide estimates of the melting regime on dirt cones. At the ice/ debris interface for Site $\mathrm{I}$, melting would continue for a minimum of $1.2 \mathrm{~h}$ after the surface temperature had passed through $0^{\circ} \mathrm{G}$ in response to changes in the local air temperature Similarly the temperature of the debris at a depth of $0.02 \mathrm{~m}$ would be in advance of the ice surface by $0.3 \mathrm{~h}$ and behind the air/debris interface by $0.9 \mathrm{~h}$. Considering the limitations of the cyclic model in Equation (5) and the experimental errors, the estimated lag between air and debris temperatures is in good agreement with those shown in Figure 9.

\section{Mechanical progesses}

Thermal conductivities for fine sediments (e.g. silt grade) may be no higher than for coarser material but when saturated they become more easily mobilized and incompetent in maintaining a cohesive layer in contact with the ice core. It would appear that it is the consistency limits which are important in determining which materials produce cones.

In silts, the Atterberg liquid limit (the minimum moisture content at which sediment will flow under its own weight (Casagrande, I947)) is lower than for finer clay sizes (Linell and Kaplar, 1959). As the moisture content in such fine-grained sediment is raised, the 
intergranular water film is thickened and the available pore space filled. This results in a flow velocity which is common to both solid and liquid phases (Bagnold, I968). The material having achieved the liquid limit through the continued supply of water from melting ice, will flow away under gravity. Beyond the coarse sand grade, increasing particle size (Fig. 8) for a given debris thickness, results in an increased permeability of the debris providing little opportunity for either saturated flow (except under pressure) see Ackermann (1948[a], [b]), or protection due to interstitial air circulation. Such processes provide the basic mechanism whereby only a limited range of sediment sizes (Fig. 8) were observed to produce distinct dirt cones.

Mass transfer, in response to such changes in the mechanical strength of the debris, was observed to be the dominant process operating upon the sediment layer. Failure of the unconsolidated debris occurred in the form of periodic slumping, sliding or avalanching, steepening and thinning the debris slope above and reducing it at the cone base to give the distinctive slope relations shown in Figure 4 .

\section{Model of Dirt-Gone Development}

On the basis of observational and experimental data, a simple, deterministic model of cone dynamics can be suggested in which cone slope angle $(\tan \alpha=2 z / y)$ and cone height $\left(h_{\mathrm{d}}\right)$ are used as critical indicators of cone growth:

$$
\tan \alpha=f\left([x y],\left[T_{\mathrm{c}} / T_{\mathrm{m}}\right], s, D_{\mathrm{a}}\right)
$$

where $x y$ is proportional to the basal cross-sectional area, $T_{\mathrm{c}} / T_{\mathrm{m}}$ is the ratio of debris thickness

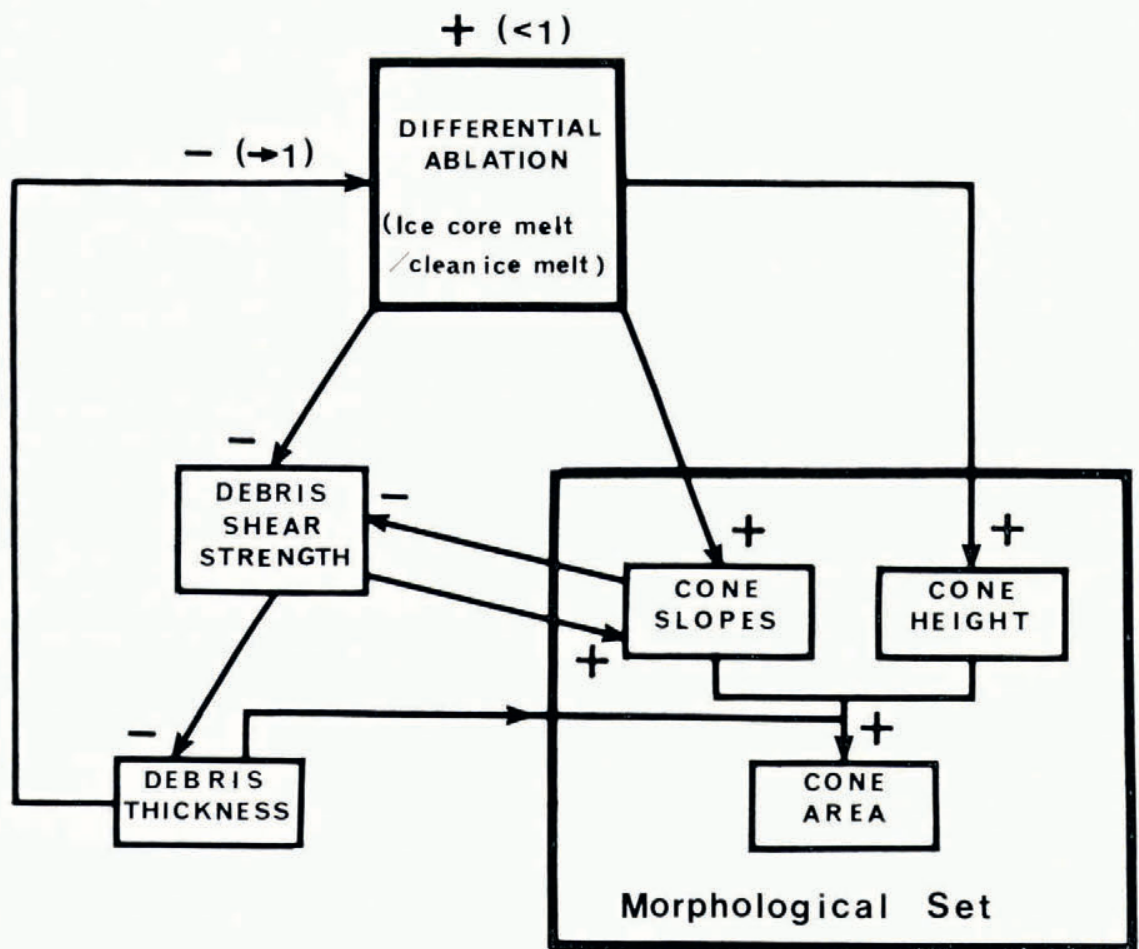

Fig. II. Feedback relationships during the growth phase of dirt cones. + indicates an increase in the variable at the head of the arrow, which is the direction of causal change. - indicates a decrease in the variable at the head of the arrow. The differential ablation ratio is initially $<I$. 
at the cone crest to the mid-slope thickness, $s$ is the shear strength of the debris layer, and $D_{\mathrm{a}}$ is the differential ablation rate (ratio of melting rate at the ice core to the melting rate over "clean" ice).

During the rapid, positive growth phase $D_{\mathrm{a}}<\mathrm{I}$. The interaction and feedback system at this stage is shown in Figure II. As the cone increases in height, the slopes steepen $\left(\theta_{\mathbf{d}}>\theta_{\mathbf{i}}\right)$, retreating towards the incipient apex. The surface area increases and the debris layer beconies thinner (by mass movement), reducing net protection and the ablation differential. But as $D_{\mathrm{a}} \rightarrow \mathrm{I}$, the interactions change (Fig. 12). Once the debris is reduced to a threshold thickness on the cone crest (Fig. 7) melting of the ice core is accelerated, the cone (as a morphological form) decays and the ablation differential is stabilized.

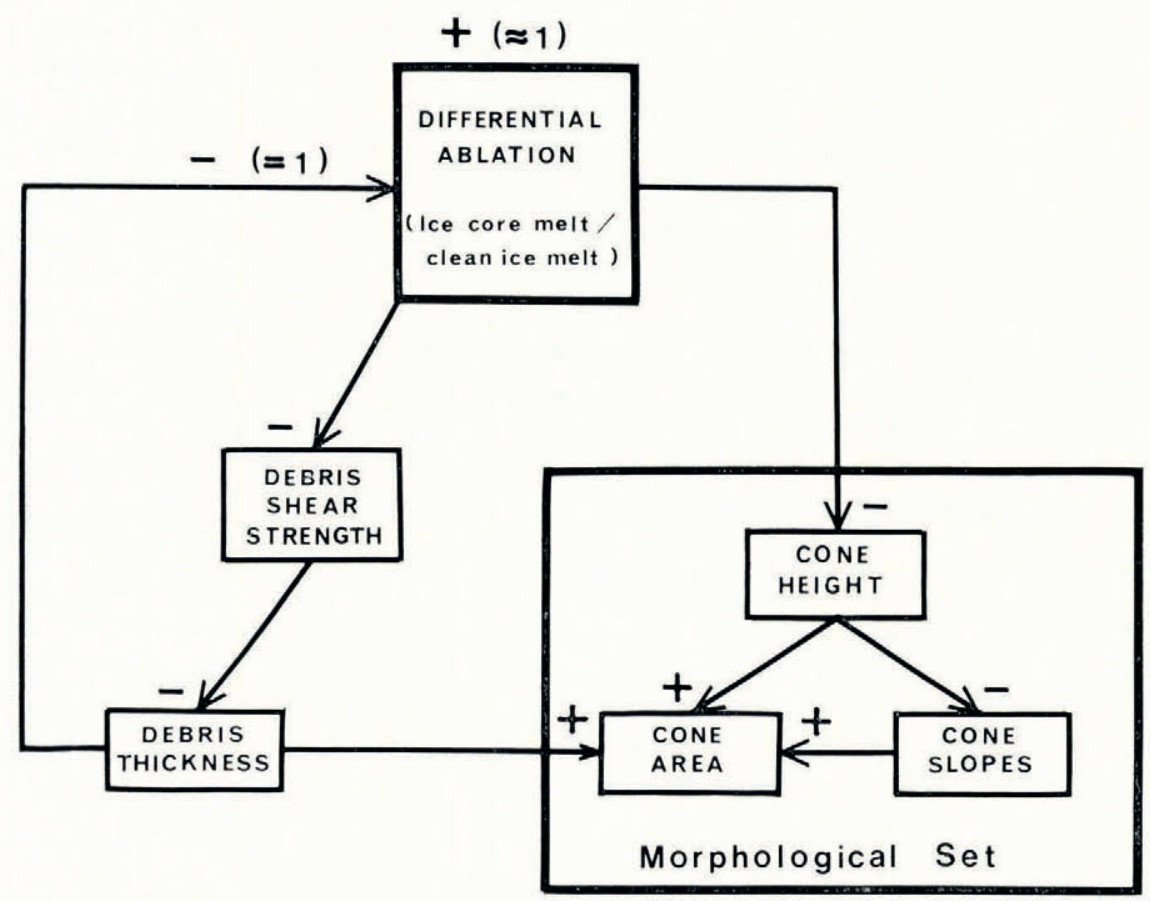

Fig. I2. Feedback relationships during the decay stage of dirt cones. Key as in Figure I2. The differential ablation ratio is close to unity.

Dirt-cone growth and form is thus a steady-state process in response to the ablation/ protection balance. The overall feedback is negative but characterized by two distinctive phases of waxing and waning development (i.e. cone form) with a change-over threshold related to debris thickness.

\section{Conclusions}

From the material and discussion outlined in previous sections a number of points have emerged. These are:

(I) Natural dirt cones on Bersaerkerbræ resulted from the differential ablation of streamlaid sediment.

(2) The material comprising the sediment cover of natural cones was found to lie predominantly within the size range $0.6 \mathrm{~mm}$ to $5 \mathrm{~mm}$. Experiments to determine the ability of 
various particle-size materials to produce dirt cones indicated that a threshold grain size could be postulated at the medium sand grade $(0.2 \mathrm{~mm}$ to $0.6 \mathrm{~mm})$. Due to the low Atterberg liquid consistency limit of fine, silty-clay materials, no cones developed in such deposits. The permeability of thin layers of coarse debris ( $10 \mathrm{~mm}$ to $200 \mathrm{~mm}$ ), affording continuous circulation of air within the fabric, probably prevented differential ablation and cone growth. Grain-size, which has not been stressed in previous studies, would seem one of the dominant controls in cone formation, its effect being independent of debris thickness within the range Io $\mathrm{mm}$ to $125 \mathrm{~mm}$.

(3) The growth rate of dirt cones varies with plot geometry and sediment thickness: (a) Since cone slope angles show little variation $(<10 \%)$ cone height is directly related to basal cross-sectional area. (b) For equivalent cross-sectional areas, cone height is a function of debris thickness. (c) Growth of cones proceeds at a rate of up to $50 \%$ of the ablation rate over "clean" ice. This implies continuous melting at the ice core crest, so that cone size is a poor gauge of ablation on the surrounding glacier.

(4) If the temperature gradient through the debris and the growth rate are known, the average thermal conductivity of the sediment can be computed and the heat transfer in response to a changing air temperature, can be estimated.

(5) A simple, deterministic model for cone development is proposed, characterized by negative feedback and describing a steady-state system.

\section{ACKNOWLedgements}

The material presented in this report was obtained during the Queen Mary College East Greenland Expedition ig68. The author would like to thank Dr R. J. Palmer and the late Mr T. A. Hird who so readily assisted in the collection of field data. The Royal Geographical Society, Queen Mary College (University of London), the Central Research Fund of the University of London, the Mount Everest Foundation and the Gino Watkins Memorial Fund provided finance and equipment. Dr H. Lister, Dr J. G. Paren and Dr G. de Q. Robin kindly read all or part of the draft and suggested improvements.

MS. received 27 February 197 I and in revised form 8 September 1971

\section{REFERENCES}

Ackermann, E. 1948[a]. Quickerden und Fliessbewegungen bei Erdrutschen. Zeitschrift der Deutschen Geologischen Gesellschaft, Bd. 100, p. 427-66. [English translation: Canada. National Research Council. Technical Translation 839, I959.]

Ackermann, E. 1948[b]. Thixotropie und Fliesseigenschaften feinkörniger Böden. Geologische Rundschau, Bd. 36 , p. 10-29. [English translation: Canada. National Research Council. Technical Translation 150, 1950.]

Agassiz, L. 1840. Études sur les glaciers. Neuchâtel, privately printed. 2 vols.

Bagnold, R. A. 1968 . Deposition in the process of hydraulic transport. Sedimentology, Vol. 10 , No. 1, p. $45-56$.

Birch, F., and others. 1942. Handbook of physical constants, by F. Birch, J. F. Schairer and H. C. Spicer. Geological Society of America. Special Papers, No. 36.

Bout, P. 1956. Les cônes de poussières des glaciers islandais. Revue de Géomorphologie Dynamique, An. $7^{\mathrm{e}}, \mathrm{Nos} .7^{-8}$, p. 97-IO9.

Brückner, E. I9o8. Schneeschmelzkegel in den Alpen und Nieve Penitente. Zeitschrift für Gletscherkunde, Bd. 2, Ht. 4, p. $301-03$.

Carslaw, H. S., and Jaeger, J. C. 1959. Conduction of heat in solids. Second edition. Oxford, Clarendon Press.

Casagrande, A. 1947. Classification and identification of soils. Proceedings of the American Society of Civil Engineers, Vol. 73 , No. 6, p. $783-810$.

Clark, S. P., ed. 1966. Handbook of physical constants. Revised edition. Geological Sociely of America. Memoir 97, p. 459-82.

Dibner, V. D., and Zagorskaya, N. G. I958. Konusoobraznyye kholmy arkticheskikh tundr. [Cone-shaped hills of Arctic tundras]. Priroda, 1958, No. 4, p. 90-93.

Fränkl, E. 1953. Die geologische Karte von Nord-Scoresby Land (NE-Grønland). Meddelelser om Grønland, Bd. I I 3, Nr. 6. 
Jakob, M., and Hawkins, G. A. 1942. Elements of heat transfer and insulation. New York, John Wiley and Sons, Inc. Krenek, L. O. 1958. The formation of dirt cones on Mount Ruapehu, New Zealand. Fournal of Glaciology, Vol. 3,

No. 24, p. 310, 312-14.
Lewis, W. V. 1940. Dirt cones on the northern margins of Vatnajökull, Iceland. Fournal of Geomorphology, Vol. 3 ,

No. 1, p. 16-26.
Linell, K. A., and Kaplar, C. W. 1959. The factor of soil and material type in frost action. Bulletin. [U.S.] Highway Research Board, 225, p. 81-126.

Lister, H. 1953. Report on glaciology at Breiðamerkurjökull, 195.I. Jökull, Ár 3, p. 23-31.

Lister, H. 1959. Micro-meteorology over dirt coned ice. Jökull, Ár 9, p. I-5.

Lliboutry, L. A. I964-65. Traité de glaciologie. Paris, Masson et Cie. 2 vols.

Markin, V. A. In press. Potentialities of artificial intensification of glacier run-off in Central Asia in connection with different weather patterns. Union Géodésique et Géophysique Internationale. Association Internationale d'Hydrologie Scientifique. Commission de Neiges et Glaces. Symposium on the hydrology of glaciers, Cambridge, $7^{-1} 3$ September 1969 , organized by the Glaciological Society. [Abstract.]

Megahan, W. F., and others. 1970. The effect of albedo-reducing materials on net radiation at a snow surface, [by] W. F. Megahan, J. R. Meiman and B. C. Goodell. Bulletin de l'Association Internationale d'Hydrologie Scientifique, $5^{\mathrm{e}}$ An., No. I, p. $69-80$.

Østrem, G. 1959. Ice melting under a thin layer of moraine, and the existence of ice cores in moraine ridges. Geografiska Annaler, Vol. 41, No. 4, p. 228-30.

Østrem, G. 1965. Problems of dating ice-cored moraines. Geografiska Annaler, Vol. 47A, No. I, p. I-38.

Sharp, R. P. I949. Studies of the supraglacial debris on valley glaciers. American Journal of Science, Vol. 247,

No. 5, p. 289-315.
Spethmann, H. 1908. Schneeschmelzkegel auf Island. Zeitschrift für Gletscherkunde, Bd. 2, Ht. 4, p. $296-30$ I.

Streiff-Becker, R. I954. The initiation of dirt cones on snow: comments on J. W. Wilson's paper. Fournal of Glaciology, Vol. 2, No. 15, p. 365-66.

Swithinbank, C. W. M. 1950. The origin of dirt cones on glaciers. Journal of Glaciology, Vol. 1, No. 8, p. 439,

$4^{6} \mathrm{r}-65$
Wijngaarden, H. van. I96r. Investigations concerning the transport of heat through a solid sheet of ice in periods of frost and thaw. Union Géodésique et Géophysique Internationale. Association Internationale d'Hydrologie Scientifique. Assemblée générale de Helsinki, 25-7-6-8 1960. Commission des Neiges et Glaces, p. 40-50.

Wilson, J. W. 1953. The initiation of dirt cones on snow. Fournal of Glaciology, Vol. 2, No. 14, p. $281-87$. 